\title{
POLLUTANT LEVELS IN EFFLUENT SAMPLES FROM TANNERIES AND TEXTILES OF KANO INDUSTRIAL AREAS, NIGERIA
}

\author{
J. C. AKAN, V. O. OGUGBUAJA, F. I. ABDULRAHMAN AND J. T. AYODELE
}

(Received 9, December 2008; Revision Accepted 1, April 2009)

\begin{abstract}
Effluent samples from tanneries and textile industries from Kano industrial area of Challawa, Bompai and Sharada industrial area were collected on quarterly basis from June to September, 2007 (Rainy season), November, 2007 - February, 2008 (Harmattan season) and March - May, 2008 (Dry season) to reflect the seasonal factors. Effluents from ten industries were sampled and determined for physicochemical parameters. The physicochemical pollutants indicators determined include; Biological oxygen demand (BOD) and Chemical oxygen demand (COD) which all depend on the concentration of dissolved oxygen (DO) in effluent samples. Anions and trace elements were also determined. The above parameters were determined using standard procedures. From the results of the study, the concentrations of BOD, COD, DO, nitrate, nitrite, sulphate, phosphate, chloride and heavy metals were higher than the limits set by $\mathrm{WHO}$ for the discharged of tanneries and textile effluents into river. Result of analysis of variance (ANOVA) showed that variations between some industries were statistically significant $(p \leq 0.05)$, but there were no marked seasonal variation in all the industries studied. Based on the high levels of the above parameters, it can be suggested that regular monitory of pollutants in the tannery and textile effluent are necessary to ensure proper discharge of these effluents into receiving river.
\end{abstract}

KEY WORDS: Pollutants, Levels, Effluent, Tanneries, Textile, Industrial Areas, Kano

\section{INTRODUCTION}

Industrial pollution is a problem and there are attempts to control it. Effluents generated by industries are sources for pollution. Contaminated air, soil, and water by effluents from industries are associated with disease burden and this could be reasons for the current shorter life expectancy (WHO, 2002; 2003) when compared with developed nations. Heavy metals in industrial effluent have been found to be carcinogenic, while others are poisonous depending on the dose and exposure period (Kupchella and Hyland, 1989; WHO, 2002). These chemicals are poisonous to man and aquatic life resulting in food contamination (Novick, 1999; WHO, 2003). For example ammonia is harmful to fish and other aquatic organisms at concentrations of 10 - $50 \mu \mathrm{g} / \mathrm{l}$, the sulphate in effluents is of environmental concern (WHO, 2002) because this may lead to poor air quality of an area. The same is applicable to $\mathrm{pH}$ if water available for human use is not of the required quality (WHO, 1993).

Textile industry can be classified into three categories viz., cotton, woolen, and synthetic depending upon the raw materials used. The water consumption and wastewater generation from a textile industry depend upon the processing operations employed during the conversion of fiber to textile fabric. Textile industries are major sources of these effluents due to the nature of their operations, which require water that results in high wastewater generation (Ghoreishi and
Haghighi, 2003). The wastewater from a textile industry is characterized by high BOD, COD, colour, and $\mathrm{pH}$ (SDPI, 1995). High BOD levels in the untreated wastewater can cause rapid depletion of dissolved oxygen if directly discharged into the surface water. Effluents with high COD are toxic to biological life (Uzo et al., 2006). The high alkalinity and traces of chromium adversely affect the aquatic life and also interfere with the biological treatment process (EPA, 2003f and p).

The textile industry is distinguished by raw materials used which determine the volume of water required and hence the wastewater generated. Production may be from raw cotton and synthetic materials. In this type of production, slashing, bleaching, mercerizing, and dyeing are the activities where wastewater generation containing high biological oxygen demand, chemical oxygen demand, total dissolved solid, total suspended solid, oil and grease, $\mathrm{pH}$, anions, temperature, colour and heavy metals are discharged with adverse effects on biological activity in water environment and man (Talbot, 1979). Specific water use in the textile industries varies from $60-400 \mathrm{l} / \mathrm{kg}$ of fabric, depending on the type of fabric (PRG, 1998).

Leather tanning and textile operations support leather shoe factories that make sandals, police boots, leather belt and bags providing finished export products and employment. There have been challenging issues regarding, resolving environmental pollution of effluents from these industries in Challawa, Sharada and Bompai industrial estates of Kano state, Nigeria (Felsner, 2003).

J. C. Akan, Department of Chemistry, Faculty of Science, University of Maiduguri, P.M.B1069, Maiduguri, Borne State, Nigeria

V. O. Ogugbuaja, Department of Chemistry, Faculty of Science, University of Maiduguri, P.M.B1069, Maiduguri, Borne State, Nigeria

F. I. Abdulrahman, Department of Chemistry, Faculty of Science, University of Maiduguri, P.M.B1069, Maiduguri, Borne State, Nigeria

J. T. Ayodele, Department of Chemistry, Bayero University, Kano State, Nigeria 
Though there are several tanneries in Kano only two had functional upgraded primary treatment plant (PTP), (Felsner, 2003).

Kano (Lat. $11^{\circ} 59 \mathrm{~m} 18.3 \mathrm{~s} \mathrm{~N}$, Long $08^{\circ} 32 \mathrm{~m}$ $05.8 \mathrm{~s}$ E) 418 meters above sea level is located in Kano State and occupies a central position in Northern Nigeria. It is one of the developed industrial cities in Nigeria. Tannery and textile are some of the dominating industries and this could be one of the reasons for her high population density (Olanrewaju, 2001). Eventually the effluent from these textile and tannery operations is discharged onto land and into water bodies without treatment. In view, of the negative impact of this effluent on the environment, the present study is aimed at determining the levels of physicochemical pollutant indicators in effluent samples from textile and tanneries industries within the study areas.

\section{MATERIALS AND METHODS}

Sampling was from three industrial areas of Kano metropolis viz Challawa, Sharada and Bompai. Effluents from ten industries in these areas were studied with emphasis on tannery and textile industries. The ten industries comprise two textile and eight tanneries, they discharge their effluents into canals, which converge at a point and flow into River Challawa. Samples were collected at the point of discharge from each industry into the discharge channel.

\section{Sample Collection}

Effluent samples were collected in plastic containers previously cleaned by washing in non-ionic detergent, rinsed with tap water and later soaked in $10 \%$ $\mathrm{HNO}_{3}$ for 24 hours and finally rinsed with deionised water prior to usage. The samples were labeled and transported to the laboratory, stored in the refrigerator at about $4^{\circ} \mathrm{C}$ prior to analysis.

\section{Determination of Organic and Anions Pollutant Indicators}

Dissolved oxygen (DO) of the effluent samples was determined using Jenway Model 9070 waterproof DO meter, while the biochemical oxygen demand (BOD) determination of the water sample in $\mathrm{mg} / \mathrm{l}$ was carried out using the Standard Methods (1976). The dissolved oxygen content was determined before and after incubation. Sample incubation was for 5 days at $20^{\circ} \mathrm{C}$ in BOD bottle and $\mathrm{BOD}_{5}$ was calculated after the incubation period. Determination of chemical oxygen demand (COD) was carried out according to the method described by Ademoroti (1996). COD was determined after oxidation of organic matter in strong tetraoxosulphate $\mathrm{VI}$ acid medium by $\mathrm{K}_{2} \mathrm{Cr}_{2} \mathrm{O}_{7}$ at $148^{\circ} \mathrm{C}$, with back titration.

\section{Determination of Heavy Metals in Effluent Samples}

The effluent samples were digested according to (Radojevic and Bashkin, 1999). A blank sample was digested so as to allow a blank correction to be made. This was done by transferring $100 \mathrm{ml}$ of distilled water into a beaker and digested as described above.

Determination of $\mathrm{Cu}, \mathrm{Zn}, \mathrm{Co}, \mathrm{Mn}, \mathrm{Mg}, \mathrm{Fe}, \mathrm{Cr}$, $\mathrm{Cd} \mathrm{As}, \mathrm{Ni}$ and $\mathrm{Pb}$ were made directly on each final solution using Perkin-Elmer Analyst 300 Atomic Absorption Spectroscopy (AAS) as described by Floyd and Hezekiah (1997).

\section{Determination of Some Anions in Effluent Samples}

The concentration of nitrate, nitrite, sulphate and phosphate were determined using a DR/2010 HACH Portable Data Logging Spectrophotometer. The spectrophotometers were checked for malfunctioning by passing standard solutions of all the parameters to be measured; Blank samples (deionized water) were passed between every three measurements of water samples to check for any eventual contamination or abnormal response of equipment. Nitrate as nitrogen was determined by the cadmium reduction metal method 8036 (Standard methods, 1976., DWAF, 1992). The cadmium metal in the added reagent reduced all nitrate in the sample to nitrite; while sulphate was determined by using Sulfa Ver methods 8051 (Standard methods, 1976., DWAF, 1992).

In the determination of chloride, one hundred (100) milliliters of the water sample was measured into a $250 \mathrm{ml}$ conical flask and $\mathrm{pH}$ was adjusted to 8 with $1 \mathrm{M}$ $\mathrm{NaOH}$. One $\mathrm{ml}$ of $\mathrm{K}_{2} \mathrm{CrO}_{4}$ indicator was then added and titrated with the $\mathrm{AgNO}_{3}$ solution. A blank titration was carried out using distilled water. Chloride $(\mathrm{mg} / \mathrm{l})$ was calculated according to (Ademoroti, 1996).

\section{RESULTS AND DISCUSSION}

The mean concentration of dissolved oxygen (DO) in tanneries and textile effluent for each seasons are as presented in Table 1. Dissolved oxygen values were consistently high in all the industries and during all the seasons sampled.

Table 1: Mean Seasonal Variation of Dissolved Oxygen (Mg/L) of Industrial Effluents From Different Industries Within Kano Industrial Areas between the Periods of 2007-2008

\begin{tabular}{lccc}
\hline INDUSTRIES & $\begin{array}{c}\text { RAINY SEASON } \\
(J U N E-S E P T E M B E R\end{array}$ & $\begin{array}{c}\text { HARMATTAN PERIOD } \\
(\text { November-February) }\end{array}$ & $\begin{array}{c}\text { DRY SEASON } \\
(\text { MARCH-MAY) }\end{array}$ \\
\hline FATA TANNARY & $34.42^{\mathrm{ab}} \pm 1.43$ & $33.12^{\mathrm{ab}} \pm 1.71$ & $32.23^{\mathrm{ab}} \pm 1.30$ \\
MAMUDA TANNARY & $32.33^{\mathrm{aa}} \pm 1.54$ & $35.21^{\mathrm{aa}} \pm 1.63$ & $36.12^{\mathrm{aa}} \pm 2.73$ \\
$\begin{array}{l}\text { MARIO JOSE } \\
\text { TANNARY }\end{array}$ & $35.21^{\mathrm{ab}} \pm 2.51$ & $33.99^{\mathrm{ab}} \pm 2.57$ & $34.66^{\mathrm{ab}} \pm 1.34$ \\
KANOTAN TANNARY & $31.23^{\mathrm{aa}} \pm 1.43$ & $32.43^{\mathrm{ab}} \pm 1.50$ & $33.44^{\mathrm{ab}} \pm 1.43$ \\
MUAZA TANNARY & $38.22^{\mathrm{ac}} \pm 1.17$ & $37.46^{\mathrm{ac}} \pm 1.47$ & $36.45^{\mathrm{aa}} \pm 1.76$ \\
\hline
\end{tabular}




\begin{tabular}{|c|c|c|c|}
\hline $\begin{array}{l}\text { GOD LITTLE } \\
\text { TANNARY }\end{array}$ & $29.42^{\mathrm{aa}} \pm 1.40$ & $31.23^{\mathrm{ab}} \pm 2.60$ & $30.26^{\mathrm{ab}} \pm 1.36$ \\
\hline $\begin{array}{l}\text { TANNORTH } \\
\text { TANNARY }\end{array}$ & $32.44^{\mathrm{aa}} \pm 1.06$ & $35.22^{\mathrm{aa}} \pm 2.11$ & $33.17^{\mathrm{ab}} \pm 1.36$ \\
\hline $\begin{array}{l}\text { UNIQUE LEATHER } \\
\text { FINISHING }\end{array}$ & $30.54^{\mathrm{aa}} \pm 1.72$ & $31.11^{\mathrm{ab}} \pm 1.32$ & $32.55^{\mathrm{ab}} \pm 1.52$ \\
\hline HOLBORN TEXTILE & $27.33^{\mathrm{ad}} \pm 1.42$ & $28.24^{\mathrm{ad}} \pm 1.22$ & $28.64^{\mathrm{ac}} \pm 1.83$ \\
\hline AFRICAN TEXTILE & $33.88^{\mathrm{aa}} \pm 2.37$ & $33.24^{\mathrm{ab}} \pm 1.32$ & $31.39^{\mathrm{ab}} \pm 1.68$ \\
\hline
\end{tabular}

The mean DO concentrations of effluent in all the industries for rainy season (June - September, 2007) ranged between $27.33 \pm 1.42$ to $38.22 \pm 1.17 \mathrm{mg} / \mathrm{l}$, for Harmattan period (November 2007 - February 2008) $28.24 \pm 1.22$ to $37.46 \pm 1.47 \mathrm{mg} / \mathrm{l}$ and $.64 \pm 1.83$ to $36.45 \pm 1.76 \mathrm{mg} / \mathrm{l}$ for dry season (March - May 2008). Muaza tannery recorded relatively higher dissolved oxygen values, while Holborn textile showed the least values in all the seasons sampled. These variations might be due to chemicals used in tannaries and textile industries which increase the organic matter leading to low DO values. Despite these variations in dissolved oxygen between industries, they were no marked or distinct variations for dissolved oxygen between seasons, indicating that the activities of these industries remain almost constant throughout the seasons.

Analysis of variance (ANOVA) indicate that variation between seasons were not statistically significantly $(p>0.05)$. Though fluctuations in DO levels were recorded within industries, all the values obtained were above the WHO (1984) and USEPA (1999) permissible limit of $4 \mathrm{mg} / \mathrm{l}$ and $5 \mathrm{mg} / \mathrm{l}$ for the discharged of effluent tanneries and textile industries into river. DO contents in all the sampling points were above the safety limits for maintenance of aquatic life of $5.00 \mathrm{mg} / \mathrm{l}$.

The mean concentration of biological oxygen demand (BOD) of the effluent based on industries and seasons are as showed in Table 2. The concentrations of BOD in the rainy season (June - September, 2007) ranged between $594.67 \pm 52.91$ to $672.70 \pm 33.72 \mathrm{mg} / \mathrm{l}$., $585.67 \pm 42.83$ to $669.20 \pm 53.72 \mathrm{mg} / \mathrm{l}$ for Harmattan period (November 2007 - February 2008) and $590.47 \pm 53.71$ to $664.30 \pm 33.72 \mathrm{mg} / \mathrm{l}$ for dry season (March - May 2008).

Table 2: Mean Seasonal Variation of Biological Oxygen Demand (Mg/L) of Industrial Effluents from Different Industries within Kano Industrial Areas between the Periods of 2007-2008

\begin{tabular}{lccc}
\hline INDUSTRIES & $\begin{array}{c}\text { RAINY SEASON } \\
(J U N E-S E P T E M B E R\end{array}$ & $\begin{array}{c}\text { HARMATTAN PERIOD } \\
(\text { November-February) }\end{array}$ & $\begin{array}{c}\text { DRY SEASON } \\
(\text { MARCH-MAY) }\end{array}$ \\
\hline FATA TANNARY & $594.67^{\mathrm{ab}} \pm 52.91$ & $585.67^{\mathrm{ab}} \pm 42.83$ & $590.47^{\mathrm{ab}} \pm 53.71$ \\
MAMUDA TANNARY & $638.00^{\mathrm{aa}} \pm 43.31$ & $644.00^{\mathrm{aa}} \pm 53.33$ & $632.60^{\mathrm{aa}} \pm 47.01$ \\
MARIO JOSE & $639.33^{\mathrm{aa}} \pm 46.23$ & $647.32^{\mathrm{aa}} \pm 42.13$ & $637.23^{\mathrm{aa}} \pm 56.23$ \\
TANNARY & $621.67^{\mathrm{ac}} \pm 73.28$ & $627.11^{\mathrm{ac}} \pm 64.28$ & $625.47^{\mathrm{ac}} \pm 63.28$ \\
KANOTAN TANNARY & $629.00^{\mathrm{ac}} \pm 61.65$ & $635.00^{\mathrm{ad}} \pm 66.15$ & $630.10^{\mathrm{ad}} \pm 42.65$ \\
MUAZA TANNARY & $612.70^{\mathrm{ad}} \pm 87.96$ & $616.75^{\mathrm{ae}} \pm 77.26$ & $609.80^{\mathrm{ae}} \pm 77.96$ \\
GOD LITTLE & $622.30^{\mathrm{ac}} \pm 61.13$ & $625.20^{\mathrm{ac}} \pm 48.43$ & $627.37^{\mathrm{ac}} \pm 66.33$ \\
TANNARY & $623.70^{\mathrm{ac}} \pm 71.68$ & $630.60^{\mathrm{ac}} \pm 56.68$ & $633.71^{\mathrm{aa}} \pm 51.68$ \\
TANNORTH TANNARY & & & $664.30^{\mathrm{ae}} \pm 33.72$ \\
UNIQUE LEATHER & $672.70^{\mathrm{ad}} \pm 33.72$ & $669.20^{\mathrm{af}} \pm 53.72$ & $624.60^{\mathrm{ac}} \pm 55.36$ \\
FINISHING & $626.00^{\mathrm{ac}} \pm 66.36$ & $619.30^{\mathrm{ae}} \pm 58.31$ & \\
HOLBORN TEXTILE & & & \\
AFRICAN TEXTILE & & &
\end{tabular}

Mean with different letters are statistically different, $P<0.05$

First superscript $=$ between seasons

Second superscript $=$ between industries 
Table 3: Mean Seasonal Variation of Chemical Oxygen Demand (Mg/L) of Industrial Effluents From Different Industries within Kano Industrial Areas between the Periods of 2007-2008

\begin{tabular}{lccr}
\hline INDUSTRIES & $\begin{array}{c}\text { RAINY SEASON } \\
\text { (June-September) }\end{array}$ & $\begin{array}{c}\text { HARMATTAN PERIOD } \\
\text { (November-February) }\end{array}$ & $\begin{array}{r}\text { DRY SEASON } \\
\text { (March-May) }\end{array}$ \\
\hline FATA TANNARY & $2412.00^{\mathrm{ab}} \pm 151.70$ & $2422.00^{\mathrm{ab}} \pm 155.11$ & $2428.00^{\mathrm{ab}} \pm 165.11$ \\
MAMUDA TANNARY & $2399.00^{\mathrm{ab}} \pm 143.50$ & $2389.00^{\mathrm{ab}} \pm 133.50$ & $2391.00^{\mathrm{ab}} \pm 146.50$ \\
MARIO JOSE TANNARY & $3451.00^{\mathrm{aa}} \pm 1910.00$ & $3441.00^{\mathrm{aa}} \pm 1810.10$ & $3447.00^{\mathrm{a} a} \pm 1710.23$ \\
KANOTAN TANNARY & $3415.00^{\mathrm{aa}} \pm 1848.00$ & $3485.00^{\mathrm{aa}} \pm 1848.03$ & $3488.00^{\mathrm{aa}} \pm 1858.33$ \\
MUAZA TANNARY & $3484.00^{\mathrm{aa}} \pm 1968.00$ & $3474.00^{\mathrm{aa}} \pm 1768.23$ & $3479.00^{\mathrm{aa}} \pm 1658.32$ \\
GOD LITTLE TANNARY & $3438.00^{\mathrm{aa}} \pm 1887.00$ & $3458.00^{\mathrm{aa}} \pm 1687.33$ & $3459.00^{\mathrm{aa}} \pm 1787.21$ \\
TANNORTH TANNARY & $3444.00^{\mathrm{aa}} \pm 1897.00$ & $3454.00^{\mathrm{aa}} \pm 1597.08$ & $3449.00^{\mathrm{aa}} \pm 1697.00$ \\
UNIQUE LEATHER FINIS & $3418.00^{\mathrm{aa}} \pm 1852.00$ & $3422.00^{\mathrm{aa}} \pm 1852.00$ & $3419.00^{\mathrm{aa}} \pm 1852.00$ \\
HOLBORN TEXTILE & $3784.00^{\mathrm{ac}} \pm 1234.00$ & $3774.00^{\mathrm{ac}} \pm 1334.00$ & $3778.00^{\mathrm{ac}} \pm 1434.22$ \\
AFRICAN TEXTILE & $3419.00^{\mathrm{aa}} \pm 1852.30$ & $3423.00^{\mathrm{aa}} \pm 1852.09$ & $3426.00^{\mathrm{aa}} \pm 1752.00$
\end{tabular}

Mean with different letters are statistically different, $\mathrm{P}<0.05$

First superscript $=$ between seasons

Second superscript $=$ between industries

All the industries gave biological oxygen demand (BOD) values higher than the recommended tolerance level stipulated by FEPA for the discharged of tanneries and textile effluents into rivers $(50 \mathrm{mg} / \mathrm{l})$. Holborn textile recorded relatively higher dissolved oxygen values of $584.67 \pm 52.91$ to $594.67 \pm 52.91 \mathrm{mg} / \mathrm{l}$, while Fata tannery showed the least values of $664.30 \pm 33.72$ to $672.70 \pm 23.42 \mathrm{mg} / \mathrm{l}$ in all the seasons sampled. These values were higher than WHO standard of $20 \mathrm{mg} / \mathrm{l}$ for effluent to be discharged into surface water.

The mean concentrations of chemical oxygen demand (COD) for all the industries and seasons are as shown in Table 3. The mean COD concentration of effluent in all the industries in the rainy season (June September, 2007) ranged between $2399.00 \pm 143.50$ to $3784.00 \pm 1234.12 \mathrm{mg} / \mathrm{l} ., \quad 2389.00 \pm 133.50$ to $3774.00 \pm 1334.21 \mathrm{mg} / \mathrm{l}$ for Harmattan period (November 2007 - February 2008) and 2391.00 \pm 146.50 to $3778.00 \pm 1434 \mathrm{mg} / \mathrm{l}$ for dry season ( March - may 2008). The values of COD were nearly uniform in all the industries studied based on seasons. Holborn textile recorded relatively higher COD values of $3774.00 \pm 1334.21$ to $3778.00 \pm 1434 \mathrm{mg} / \mathrm{l}$, while Mamuda tannery showed the least values of $2389.00 \pm 133.50$ to $2399.00 \pm 143.50 \mathrm{mg} / \mathrm{l}$ in all the seasons sampled. These values were higher than WHO, USEPA standard of 1000 $\mathrm{mg} / \mathrm{l}$ for discharged of tanneries and textile effluent into surface water.

These high levels of BOD and COD values observed in all the industries may be due to high amount of organic matter from various chemicals used during the soaking, tanning and post tanning processing of hides and skins and chemicals used in textile industries for mercerizing, bleaching / scouring and yeing which include sodium sulphite, sodium bisulphate, sodium chlorite, $\mathrm{NaCl}, \mathrm{H}_{2} \mathrm{SO}_{4}$, formic acid, sodium formate, sodium bicarbonate,

vegetable tannins, syntans, resins, polyurethane, dyes, fat emulsions, pigments, binders, waxes, lacquers and formaldehyde, sodium hypochlorite, $\mathrm{C}_{12}, \mathrm{NaOH}, \mathrm{H}_{2} \mathrm{O}_{2}$, acids, surfactants, $\mathrm{NaSiO}_{3}$ and sodium phosphate. It has been reported that only about $20 \%$ of the large number of chemicals used in the tanning process is absorbed by leather, the rest is released as waste (UNIDO, 2005), thereby increasing the levels of BOD in the effluent.

Result of analysis of variance (ANOVA) showed that variation between industries were statistically different $(p<0.05)$ with exception of Holborn textile and Fata tannery, but there were no marked seasonal variation of $B O D$ and $C O D$ in all the industries studied. These results show that the discharged of effluent and the activities by these industries remained almost constant throughout the sampling periods.

The results for heavy metals concentration in effluent samples from different industries and seasons are as presented in Figure $1 \mathrm{a}, \mathrm{b}$ and $\mathrm{c}$. The composition of heavy metals in the effluent samples ranged from 8.00 to $12.60 \mathrm{mg} / \mathrm{l}$ for $\mathrm{Cr} ; 2.00$ to $5.00 \mathrm{mg} / \mathrm{l} \mathrm{Mn;} 2.77$ to $6.40 \mathrm{mg} / \mathrm{l} \mathrm{Mg} ; 2.00$ to $7.02 \mathrm{mg} / \mathrm{l} \mathrm{Fe} ; 1.33$ to $4.00 \mathrm{mg} / \mathrm{l} \mathrm{Cu}$; 2.00 to $4.22 \mathrm{mg} / \mathrm{l} \mathrm{Co} ; 0.34$ to $2.00 \mathrm{mg} / \mathrm{l} \mathrm{As}, 9.00$ to 12.44 $\mathrm{mg} / \mathrm{l} \mathrm{Ni} ; 2.40$ to $4.03 \mathrm{mg} / \mathrm{l} \mathrm{Pb} ; 3.00$ to $7.33 \mathrm{mg} / \mathrm{l} \mathrm{Zn;} \mathrm{and}$ 1.00 to $3.20 \mathrm{mg} / \mathrm{l} \mathrm{Cd}$ for rainy season (June September, 2007) Figure 1a. 8.22 to $12.50 \mathrm{mg} / \mathrm{l}$ for $\mathrm{Cr}$; 2.10 to $5.30 \mathrm{mg} / \mathrm{l} \mathrm{Mn;} 2.97$ to $6.20 \mathrm{mg} / \mathrm{l} \mathrm{Mg} ; 2.20$ to 7.42 $\mathrm{mg} / \mathrm{Fe} ; 1.39$ to $4.10 \mathrm{mg} / \mathrm{l} \mathrm{Cu} ; 2.30$ to $4.12 \mathrm{mg} / \mathrm{l} \mathrm{Co} ; 0.44$ to $2.00 \mathrm{mg} / \mathrm{l} \mathrm{As}, 9.20$ to $12.56 \mathrm{mg} / \mathrm{l} \mathrm{Ni} ; 2.33$ to $4.22 \mathrm{mg} / \mathrm{l}$ $\mathrm{Pb} ; 3.20$ to $7.11 \mathrm{mg} / \mathrm{l} \mathrm{n}$; and 1.20 to $3.14 \mathrm{mg} / \mathrm{l} \mathrm{Cd}$ for Harmattan period (November 2007 - February 2008) Figure 1 b. 8.01 to $12.59 \mathrm{mg} / \mathrm{l}$ for $\mathrm{Cr} ; 2.14$ to $5.38 \mathrm{mg} / \mathrm{l}$ $\mathrm{Mn} ; 2.92$ to $6.20 \mathrm{mg} / \mathrm{l} \mathrm{Mg} ; 2.25$ to $7.10 \mathrm{mg} / \mathrm{l} \mathrm{Fe} ; 1.29$ to $4.16 \mathrm{mg} / \mathrm{l} \mathrm{Cu} ; 2.26$ to $4.13 \mathrm{mg} / \mathrm{l} \mathrm{Co} ; 0.39$ to $2.11 \mathrm{mg} / \mathrm{l} \mathrm{As}$, 
9.26 to $12.66 \mathrm{mg} / \mathrm{l} \mathrm{Ni} ; 2.33$ to $4.32 \mathrm{mg} / \mathrm{l} \mathrm{Pb} ; 3.23$ to 7.10 $\mathrm{mg} / \mathrm{l} \mathrm{Zn}$; and 1.22 to $3.11 \mathrm{mg} / \mathrm{l} \mathrm{Cd}$ for dry season ( March - May 2008) Figure 1c. In general, the trend in heavy metal variability and mean concentrations in the effluent samples were $\mathrm{Cr}>\mathrm{Ni}>\mathrm{Zn}>\mathrm{Mg}>\mathrm{Fe}>\mathrm{Mn}>\mathrm{Pb}>$ $\mathrm{Co}>\mathrm{Cu}>\mathrm{Cd}>\mathrm{As}$, respectively. The values of heavy metals were nearly uniform in all the industries studied. These values were higher than WHO/USEPA standard of $0.1 \mathrm{mg} / \mathrm{l} \mathrm{Cr} ; 00.10 \mathrm{mg} / \mathrm{l} \mathrm{Ni} ; 1.0 \mathrm{mg} / \mathrm{Z} \mathrm{Zn;} 1.0 \mathrm{mg} / \mathrm{l} \mathrm{Mg}$; $0.30 \mathrm{mg} / \mathrm{l} \mathrm{Fe} ; 1.0 \mathrm{mg} / \mathrm{l} \mathrm{Mn} ; 0.2 \mathrm{mg} / \mathrm{l} \mathrm{Pb} ; 1.00 \mathrm{mg} / \mathrm{l} \mathrm{Cu}$; $1.00 \mathrm{mg} / \mathrm{l} \mathrm{Co} ; 0.03 \mathrm{mg} / \mathrm{l} \mathrm{Cd}$ and $0.10 \mathrm{mg} / \mathrm{l}$ As for the discharged of tanneries and textile effluent into surface water. These high values of heavy metals observed in all the effluent may be due to the chemicals used by tanneries and textile industries which contain high concentration of these metals, chromium and other heavy metals are mainly found in waste from the chrome tanning process and other chemicals, it occurs as part of the retanning system and is displaced from leathers and fabric during retanning and dyeing processes. Result of analysis of variance (ANOVA) showed that variation between some industries were significantly different $(p<0.05)$, but there were no marked seasonal variation in all the industries studied.

\section{IIC IMn IMg IFe ICU ICO $\|$ AS IN}

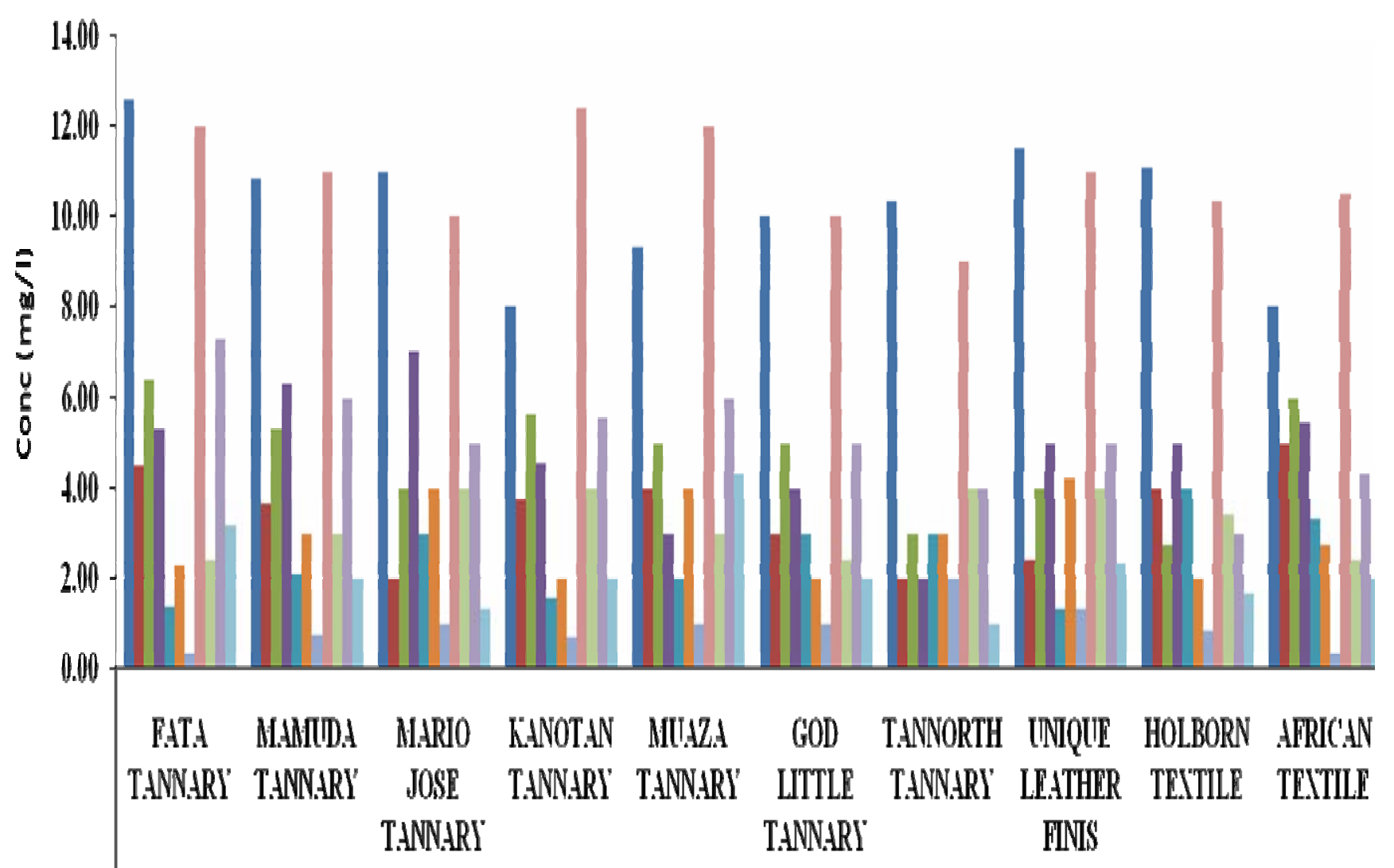

RIINISEASON

Figure 1a: Trace element concentrations / $m g / / /$ in effluent samples from different industries of Kano industrial area for rainy season 


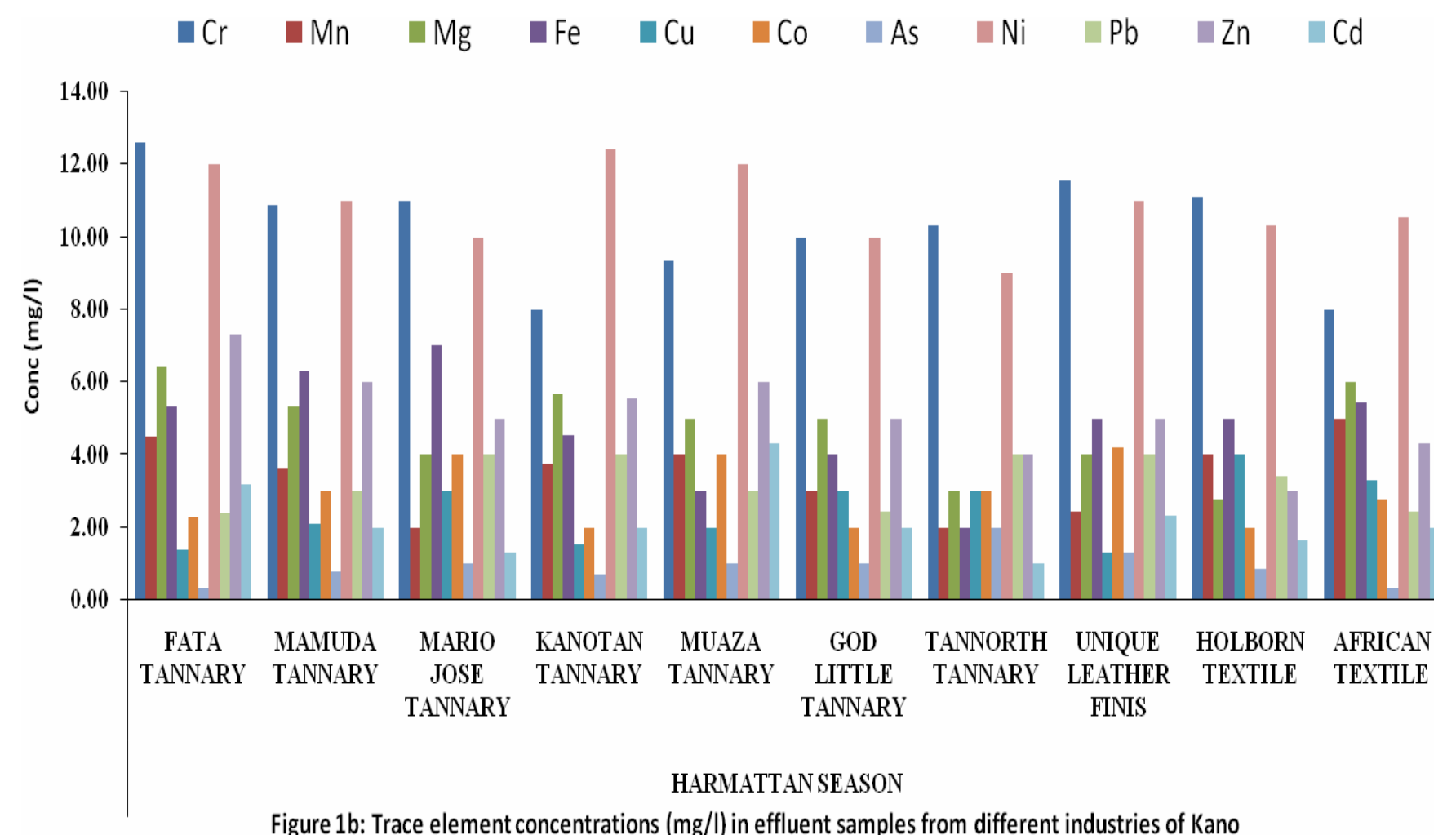

Figure $1 \mathrm{~b}$ : Trace element concentrations $(\mathrm{mg} / \mathrm{l})$ in effluent samples from different industries of Kano industrial area for Harmattan season

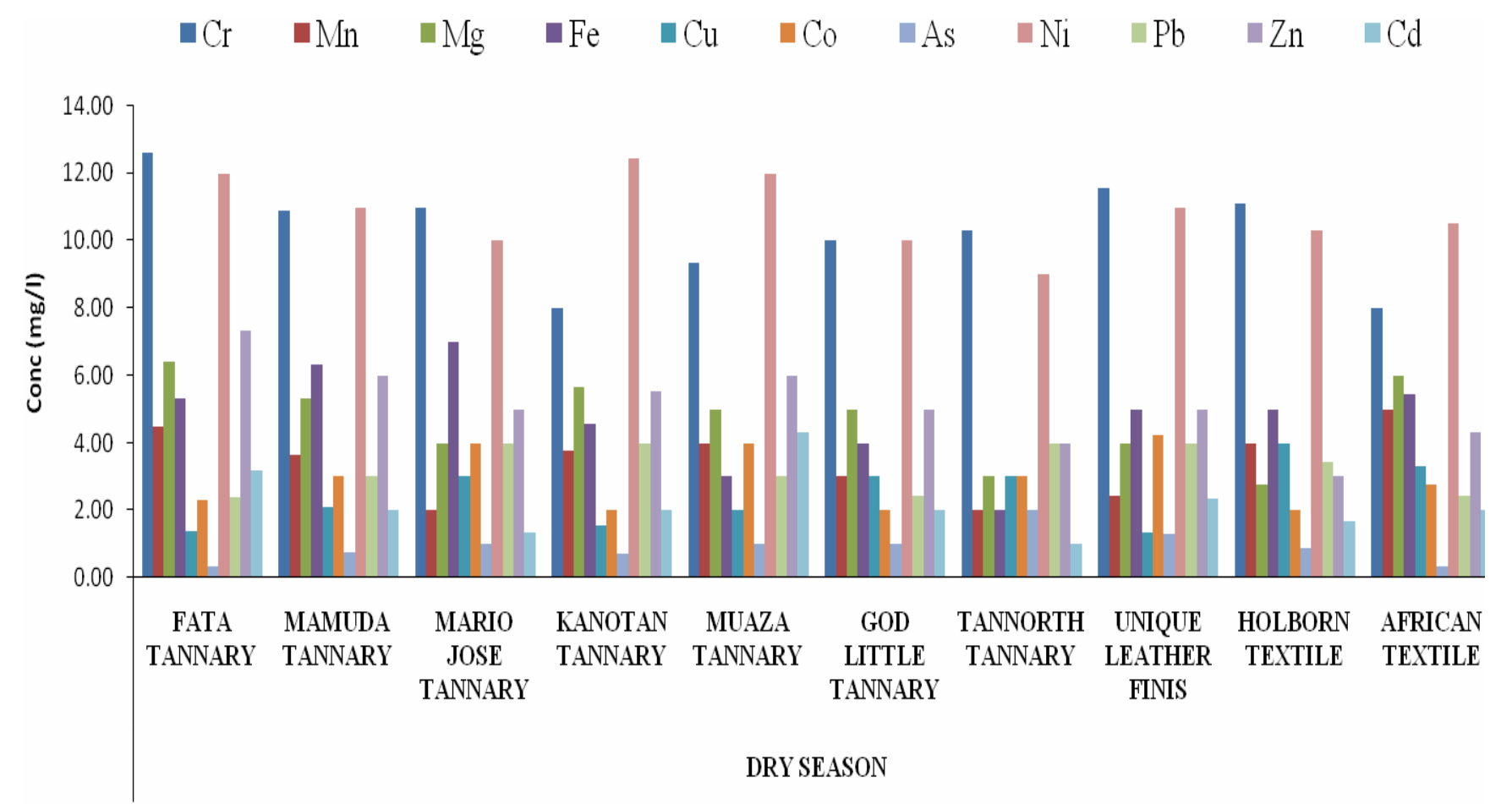

Figure 1c: Trace element concentrations $(\mathrm{mg} / \mathrm{l})$ in effluent samples from different industries of Kano industrial area for dry season 
The mean seasonal variation of nitrate concentrations in the effluent samples from different industries within Bompai, Sharada and Challawa industrial estate are illustrated in Table 4, while levels of nitrite and phosphate are as presented in Tables 5 and 6 respectively. The mean nitrate concentration of effluent in all the industries in the rainy season (June September, 2007) ranged between 59.22 \pm 3.22 to $95.24 \pm 3.29 \mathrm{mg} / \mathrm{l}$., $58.32 \pm 2.52$ to $93.22 \pm 1.23 \mathrm{mg} / \mathrm{l}$ for Harmattan period (November 2007 - February 2008) and $57.88 \pm 2.22$ to $94.77 \pm 2.01 \mathrm{mg} / \mathrm{l}$ for dry season (March - May 2008), while the mean levels of nitrite in industrial effluent from all the industries in the rainy season (June - September, 2007) ranged between $134.22 \pm 7.12$ to $193.33 \pm 6.43 \mathrm{mg} / \mathrm{l} ., 136.22 \pm 2.44$ to $196.44 \pm 5.32 \mathrm{mg} / \mathrm{l}$ for Harmattan period (November 2007 - February 2008) and $137.22 \pm 3.17$ to $192.44 \pm 7.02 \mathrm{mg} / \mathrm{l}$ for dry season (March - May 2008). The mean concentrations of phosphate in industrial effluent from all the industries in the rainy season (June - September, 2007) ranged between $16.44 \pm 3.76$ to $19.33 \pm 1.43 \mathrm{mg} / \mathrm{l}$., $16.65 \pm 2.92$ to $19.77 \pm 5.32 \mathrm{mg} / \mathrm{l}$ for Harmattan period (November 2007 - February 2008) and 16.65 \pm 1.11 to $19.93 \pm 2.02 \mathrm{mg} / \mathrm{l}$ for dry season (March - May 2008).

Table 4: Mean Seasonal Variation of Nitrate $(\mathrm{Mg} / \mathrm{L})$ in Industrial Effluents from Different Industries within Kano Industrial Areas between the Periods of 2007-2008

INDUSTRIES
RAINY SEASON

HARMATTAN PERIOD
(November-February)
(JUNE-SEPTEMBER)

(MARCH-MAY)

\section{FATA TANNARY}

MAMUDA TANNARY

MARIO JOSE TANNARY

KANOTAN TANNARY

MUAZA TANNARY

GOD LITTLE TANNARY

TANNORTH TANNARY

UNIQUE LEATHER FINIS

$$
\begin{aligned}
& 84.36^{\mathrm{ab}} \pm 6.33 \\
& 85.66^{\mathrm{ab}} \pm 2.10 \\
& 95.24^{\mathrm{aa}} \pm 3.29 \\
& 76.21^{\mathrm{ac}} \pm 2.08 \\
& 83.12^{\mathrm{ab}} \pm 1.54 \\
& 74.22^{\mathrm{ac}} \pm 2.45 \\
& 76.56^{\mathrm{ac}} \pm 1.03 \\
& 59.22^{\mathrm{ad}} \pm 3.22
\end{aligned}
$$

$$
86.77^{\mathrm{ab}} \pm 3.45
$$$$
87.34^{\mathrm{ab}} \pm 7.44
$$$$
93.22^{\mathrm{aa}} \pm 1.23
$$$$
78.23^{\mathrm{ac}} \pm 2.30
$$$$
84.06^{\mathrm{ab}} \pm 2.10
$$$$
73.06^{\mathrm{ac}} \pm 1.03
$$$$
77.23^{\mathrm{ac}} \pm 4.20
$$$$
58.32^{\mathrm{ad}} \pm 2.52
$$$$
87.00^{\mathrm{ab}} \pm 4.21
$$$$
86.23^{\mathrm{ab}} \pm 4.77
$$$$
94.77^{\mathrm{aa}} \pm 2.01
$$$$
77.12^{\mathrm{ac}} \pm 1.22
$$$$
81.43^{\mathrm{ab}} \pm 3.59
$$$$
72.00^{\mathrm{ad}} \pm 3.22
$$$$
76.21^{\mathrm{ac}} \pm 2.12
$$$$
57.88^{\mathrm{ae}} \pm 2.22
$$

HOLBORN TEXTILE

AFRICAN TEXTILE

$$
87.23^{\mathrm{ab}} \pm 3.43
$$

$87.60^{\mathrm{ab}} \pm 6.32$

\begin{tabular}{|c|c|c|c|}
\hline INDUSTRIES & $\begin{array}{r}\text { RAINY SEASON } \\
\text { (JUNE-SEPTEMBER) }\end{array}$ & $\begin{array}{l}\text { HARMATTAN PERIOD } \\
\text { (November-February) }\end{array}$ & $\begin{array}{l}\text { DRY SEASON } \\
\text { (MARCH-MAY) }\end{array}$ \\
\hline FATA TANNARY & $145.21^{\mathrm{ab}} \pm 4.13$ & $146.43^{\mathrm{ab}} \pm 3.25$ & $144.32^{\mathrm{ab}} \pm 6.43$ \\
\hline MAMUDA TANNARY & $134.22^{\mathrm{aa}} \pm 7.12$ & $136.22^{\mathrm{aa}} \pm 2.44$ & $137.22^{\mathrm{aa}} \pm 3.17$ \\
\hline MARIO JOSE TANNARY & $174.22^{\mathrm{ac}} \pm 5.34$ & $176.32^{\mathrm{ac}} \pm 4.32$ & $175.23^{\mathrm{ac}} \pm 5.01$ \\
\hline KANOTAN TANNARY & $165.54^{\mathrm{ad}} \pm 3.08$ & $164.00^{\mathrm{ad}} \pm 7.30$ & $166.54^{\mathrm{ad}} \pm 6.22$ \\
\hline MUAZA TANNARY & $168.54^{\mathrm{ad}} \pm 2.54$ & $167.55^{\mathrm{ad}} \pm 9.10$ & $165.43^{\mathrm{ad}} \pm 7.09$ \\
\hline GOD LITTLE TANNARY & $183.33^{\mathrm{ae}} \pm 6.45$ & $184.62^{\mathrm{ae}} \pm 5.03$ & $185.32^{\mathrm{ae}} \pm 8.22$ \\
\hline TANNORTH TANNARY & $176.23^{\mathrm{ac}} \pm 2.90$ & $177.55^{\mathrm{ac}} \pm 2.20$ & $175.54^{\mathrm{ac}} \pm 4.22$ \\
\hline $\begin{array}{l}\text { UNIQUE LEATHER } \\
\text { FINIS }\end{array}$ & $163.45^{\mathrm{ad}} \pm 7.32$ & $164.43^{\mathrm{ad}} \pm 7.52$ & $162.00^{\mathrm{ad}} \pm 3.22$ \\
\hline HOLBORN TEXTILE & $193.33^{\mathrm{af}} \pm 6.43$ & $196.44^{\mathrm{af}} \pm 5.32$ & $192.44^{\mathrm{af}} \pm 7.02$ \\
\hline AFRICAN TEXTILE & $188.34^{\mathrm{ae}} \pm 0.76$ & $186.65^{\mathrm{ae}} \pm 3.92$ & $187.44^{\mathrm{ae}} \pm 5.11$ \\
\hline
\end{tabular}

$86.20^{\mathrm{ab}} \pm 3.02$

$78.13^{\mathrm{ac}} \pm 1.76$

Mean with different letters are statistically different, $P<0.05$

First superscript $=$ between seasons

Second superscript $=$ between industries

Table 5: Mean Seasonal Variation of Nitrite (Mg/L) in Industrial Effluents from Different Industries within Kano Industrial Areas between the Periods of 2007-2008 
Mean with different letters are statistically different, $\mathrm{P}<0.05$

First superscript $=$ between seasons

Second superscript $=$ between industries

Table 6: Mean Seasonal Variation of Phosphate (Mg/L) in Industrial Effluents from Different Industries within Kano Industrial Areas between the Periods of 2007-2008

\begin{tabular}{lccc}
\hline INDUSTRIES & $\begin{array}{c}\text { RAINY SEASON } \\
(\text { JUNE-SEPTEMBER) }\end{array}$ & $\begin{array}{c}\text { HARMATTAN PERIOD } \\
(\text { November-February) }\end{array}$ & $\begin{array}{c}\text { DRY SEASON } \\
(\text { MARCH-MAY) }\end{array}$ \\
\hline FATA TANNARY & $18.39^{\mathrm{ab}} \pm 0.52$ & $18.87^{\mathrm{ab}} \pm 2.25$ & $19.23^{\mathrm{ab}} \pm 3.43$ \\
MAMUDA TANNARY & $19.22^{\mathrm{ab}} \pm 4.12$ & $18.87^{\mathrm{ab}} \pm 1.44$ & $19.00^{\mathrm{ab}} \pm 1.14$ \\
MARIO JOSE TANNARY & $17.00^{\mathrm{ac}} \pm 2.34$ & $18.98^{\mathrm{ac}} \pm 3.32$ & $17.56^{\mathrm{ac}} \pm 3.21$ \\
KANOTAN TANNARY & $16.46^{\mathrm{ac}} \pm 1.08$ & $16.99^{\mathrm{ac}} \pm 1.37$ & $16.68^{\mathrm{ac}} \pm 2.52$ \\
MUAZA TANNARY & $18.11^{\mathrm{ab}} \pm 2.54$ & $18.65^{\mathrm{ab}} \pm 1.10$ & $18.45^{\mathrm{ab}} \pm 1.09$ \\
GOD LITTLE TANNARY & $19.22^{\mathrm{ab}} \pm 1.45$ & $19.00^{\mathrm{ab}} \pm 2.03$ & $19.43^{\mathrm{ab}} \pm 1.22$ \\
TANNORTH TANNARY & $18.43^{\mathrm{ab}} \pm 2.90$ & $18.56^{\mathrm{ab}} \pm 2.20$ & $18.91^{\mathrm{ab}} \pm 4.22$ \\
UNIQUE LEATHER & $17.77^{\mathrm{ac}} \pm 3.32$ & $17.65^{\mathrm{ac}} \pm 2.52$ & $17.32^{\mathrm{ac}} \pm 1.22$ \\
FINIS & $19.33^{\mathrm{ab}} \pm 1.43$ & & $19.93^{\mathrm{ab}} \pm 2.02$ \\
HOLBORN TEXTILE & $16.44^{\mathrm{ac}} \pm 3.76$ & $19.77^{\mathrm{ab}} \pm 5.32$ & $16.65^{\mathrm{ac}} \pm 1.11$ \\
\hline AFRICAN TEXTILE & $16.65^{\mathrm{ac}} \pm 2.92$ &
\end{tabular}

Mean with different letters are statistically different, $\mathrm{P}<0.05$

First superscript $=$ between seasons

Second superscript $=$ between industries

Mario Jose tannery recorded the highest concentration of nitrate $(93.22 \pm 1.23$ to $95.24 \pm 3.29 \mathrm{mg} / \mathrm{l})$ in comparison to other industries under study throughout the seasons, while low nitrate level of $57.88 \pm 2.22$ to $59.22 \pm 3.22 \mathrm{mg} / \mathrm{l}$ was observed in Unique leather finishing. For nitrite concentrations, Holborn textile recorded the highest concentration of $192.44 \pm 7.02$ to $196.44 \pm 5.32 \mathrm{mg} / \mathrm{l}$ throughout the seasons, while Mamuda tannery shows the least concentrations of nitrite $(134.22 \pm 7.12$ to $137.22 \pm 3.17 \mathrm{mg} / \mathrm{l})$. Phosphate levels were highest in

Holborn textile throughout the seasons $(19.33 \pm 1.43$ to $19.93 \pm 2.02 \mathrm{mg} / \mathrm{l})$, while the least concentration was observed in African textile $(16.44 \pm 3.76$ to16.65 \pm 1.11 $\mathrm{mg} / \mathrm{l}$. The mean nitrate, nitrite and phosphate concentrations recorded for all the industries in this study were above the stipulated WHO/USEPA/FEPA tolerance limit of between $45 \mathrm{mg} / \mathrm{l}, 25 \mathrm{mg} / \mathrm{l}$ and $5 \mathrm{mg} / \mathrm{l}$ respectively for effluents to be discharged from tanneries and textile industries into river or stream. These high levels of nitrate, nitrite in the entire industries might be attributed to several components in tannery effluent containing nitrogen as part of the chemical structure and the nitrogen contained in proteinaceous material (from liming unhairy operation) (Bosnic et al., 2000).

The mean concentrations of sulphate for all the industries and seasons are shown in Table 7. While the chloride for all the industries and seasons are shown in
Table 8. The mean sulphate concentration of effluent in all the industries in the rainy season (June - September, 2007) ranged between $545.34 \pm 2.32$ to $978.13 \pm 11.76$ mg/l., $552.22 \pm 2.47$ to980.00 $\pm 12.43 \mathrm{mg} / \mathrm{l}$ for Harmattan period (November 2007 - February 2008) and $548.31 \pm 3.22$ to $976.05 \pm 13.11 \mathrm{mg} / \mathrm{l}$ for dry season (March - may 2008). The concentrations of chloride ranged from $175.90 \pm 9.54$ to $654.15 \pm 111.76 \mathrm{mg} / \mathrm{l}$ for rainy season (June - September, 2007)., 174.97 \pm 10.34 to $658.32 \pm 212.43 \mathrm{mg} / \mathrm{l}$ Harmattan period (November 2007 - February 2008)., 176.45 \pm 15.01 to $636.12 \pm 233.11 \mathrm{mg} / \mathrm{l}$ for dry season ( March - may 2008). African textile recorded relatively higher sulphate values, while Kanotan tannery showed the least values. These values were higher than the WHO, USEPA standard of 250 $\mathrm{mg} / \mathrm{l}$ sulphate for the discharged of tanneries and textile effluent into surface water. The South African quideline for sulphate in effluent is $0.2 \mathrm{mg} / \mathrm{l}$, this limit was exceeded. These high levels of sulphate observed in all the effluent may be due to the fact that sulphates are compounds of tanneries and textile effluent emanating from the use of sulphuric acid or product with high sodium sulphate content. These high concentrations of sulphate in all the tanneries and textile effluent may also be attributed to the fact that many auxiliary chemicals used in these industries contain sodium sulphate as a by-product of the manufacturer or chrome tanning powders containing high levels of sodium sulphate (Bosnic et al., 2000). 
Table 7: Mean Seasonal Variation of Sulphate (Mg/L) in Industrial Effluents from different Industries within Kano Industrial Areas between the Periods of 2007-2008

\begin{tabular}{|c|c|c|c|}
\hline INDUSTRIES & $\begin{array}{c}\text { RAINY SEASON } \\
\text { (JUNE-SEPTEMBER) }\end{array}$ & $\begin{array}{l}\text { HARMATTAN PERIOD } \\
\text { (November-February) }\end{array}$ & $\begin{array}{l}\text { DRY SEASON } \\
\text { (MARCH-MAY) }\end{array}$ \\
\hline FATA TANNARY & $834.22^{\mathrm{ab}} \pm 6.33$ & $838.23^{\mathrm{ab}} \pm 3.45$ & $841.12^{\mathrm{ab}} \pm 12.21$ \\
\hline MAMUDA TANNARY & $812.32^{\mathrm{ab}} \pm 5.35$ & $815.22^{\mathrm{ab}} \pm 7.14$ & $810.34^{\mathrm{ab}} \pm 8.34$ \\
\hline MARIO JOSE TANNARY & $943.23^{\mathrm{aa}} \pm 12.23$ & $948.34^{\mathrm{aa}} \pm 10.21$ & $942.23^{\mathrm{aa}} \pm 14.53$ \\
\hline KANOTAN TANNARY & $545.34^{\mathrm{ac}} \pm 2.32$ & $552.22^{\mathrm{ac}} \pm 2.47$ & $548.31^{\mathrm{ac}} \pm 3.22$ \\
\hline MUAZA TANNARY & $674.65^{\mathrm{ad}} \pm 4.34$ & $678.00^{\mathrm{ad}} \pm 2.90$ & $671.21^{\mathrm{ad}} \pm 3.59$ \\
\hline GOD LITTLE TANNARY & $746.90^{\mathrm{ae}} \pm 3.45$ & $738.06^{\mathrm{ae}} \pm 4.03$ & $741.22^{\mathrm{ae}} \pm 14.76$ \\
\hline TANNORTH TANNARY & $664.33^{\mathrm{ad}} \pm 5.50$ & $667.22^{\mathrm{ad}} \pm 4.44$ & $661.11^{\mathrm{ad}} \pm 2.70$ \\
\hline UNIQUE LEATHER FINIS & $567.21^{\mathrm{ac}} \pm 5.22$ & $564.00^{\mathrm{ac}} \pm 7.55$ & $569.00^{\mathrm{ac}} \pm 3.22$ \\
\hline HOLBORN TEXTILE & $878.00^{\mathrm{ab}} \pm 6.43$ & $874.20^{\mathrm{ab}} \pm 8.32$ & $876.20^{\mathrm{ab}} \pm 7.82$ \\
\hline AFRICAN TEXTILE & $978.13^{\mathrm{af}} \pm 11.76$ & $980.00^{\mathrm{af}} \pm 12.43$ & $976.05^{\mathrm{af}} \pm 13.11$ \\
\hline
\end{tabular}

Table 8: Mean Seasonal Variation of Chloride (Mg/L) in Industrial Effluents from different Industries within Kano Industrial Areas between the Periods of 2007-2008

\begin{tabular}{|c|c|c|c|}
\hline INDUSTRIES & $\begin{array}{c}\text { RAINY SEASON } \\
\text { (JUNE-SEPTEMBER) }\end{array}$ & $\begin{array}{l}\text { HARMATTAN PERIOD } \\
\text { (November-February) }\end{array}$ & $\begin{array}{l}\text { DRY SEASON } \\
\text { (MARCH-MAY) }\end{array}$ \\
\hline FATA TANNARY & $314.12^{\mathrm{ab}} \pm 34.09$ & $311.00^{\mathrm{ab}} \pm 32.11$ & $322.21^{\mathrm{ab}} \pm 22.92$ \\
\hline MAMUDA TANNARY & $253.11^{\mathrm{aa}} \pm 11.10$ & $247.32^{\mathrm{aa}} \pm 12.00$ & $249.54^{\mathrm{aa}} \pm 13.83$ \\
\hline MARIO JOSE TANNARY & $287.04^{\mathrm{ac}} \pm 16.32$ & $286.03^{\mathrm{ac}} \pm 15.43$ & $288.00^{\mathrm{ac}} \pm 12.65$ \\
\hline KANOTAN TANNARY & $223.11^{\mathrm{ad}} \pm 10.21$ & $227.26^{\mathrm{ad}} \pm 14.54$ & $229.00^{\mathrm{ad}} \pm 21.21$ \\
\hline MUAZA TANNARY & $221.21^{\mathrm{ad}} \pm 12.81$ & $222.77^{\mathrm{ad}} \pm 11.08$ & $231.39^{\mathrm{ad}} \pm 17.21$ \\
\hline GOD LITTLE TANNARY & $189.00^{\mathrm{ae}} \pm 12.11$ & $191.32^{\mathrm{ae}} \pm 21.03$ & $188.04^{\mathrm{ae}} \pm 14.76$ \\
\hline TANNORTH TANNARY & $175.90^{\mathrm{ae}} \pm 9.54$ & $174.97^{\mathrm{ae}} \pm 10.34$ & $176.45^{\mathrm{ae}} \pm 15.01$ \\
\hline UNIQUE LEATHER FINIS & $231.30^{\mathrm{ad}} \pm 11.90$ & $234.77^{\mathrm{ad}} \pm 16.55$ & $232.00^{\mathrm{ad}} \pm 13.87$ \\
\hline HOLBORN TEXTILE & $621.12^{\text {af }} \pm 231.21$ & $625.65^{\text {af }} \pm 211.10$ & $623.33^{\mathrm{af}} \pm 251.82$ \\
\hline AFRICAN TEXTILE & $654.15^{\mathrm{af}} \pm 111.76$ & $658.32^{\mathrm{af}} \pm 212.43$ & $636.12^{\text {af }} \pm 233.11$ \\
\hline
\end{tabular}

The values of chloride in all the industries under study were higher than the WHO standard of $150 \mathrm{mg} / \mathrm{l}$ for the discharged of tannery and textile effluent into rivers. The high values of chloride in the effluent might be due to the fact that chloride are introduced into tannery effluents as sodium chloride usually on account of the large quantities of common salt used in hide and skin preservation or the pickling process, being highly soluble and stable, they are unaffected by effluent treatment and nature, thus remaining as a burden on the environment (Bhatia, 2005, Bosnic et al., 2000).

Result of analysis of variance (ANOVA) showed that variation between industries were statistically significant $(p<0.05)$ with exception of some industries, but there were no marked seasonal variation for nitrate, nitrite, phosphate sulphate and chloride in all the industries studied. 


\section{SUMMARY AND CONCLUSION}

The levels of dissolved oxygen (DO), chemical oxygen demand (COD) and biological oxygen demand (BOD) in all the industries were found to be higher than the optimum ranged for the discharge of tannery and textile effluent into river and stream. High concentrations of heavy metals were observed to accumulate in all the effluent samples from tanneries and textile industries studied. The concentrations of sulphate, chloride, nitrate, nitrite and phosphate of effluent in all the industries sample studied were higher than the USEPA limits for the discharge of industrial effluent into river

\section{REFERENCES}

Ademoroti, C. M. A., 1996. Standard method for water and Effluents Analysis. Foludex press Ltd, Ibadan pp.22-23, 44-54, 111-112.

Bhatia, S. C., 2005. Environmental pollution and Control in chemical process industries. Publish by Romesh Chander Khanna for Khanna publishers 2-B Nath Market, Nai Sarak Delhi110006. pp 772-831.

Bosnic, M., Buljan, J., Daniels, R. P., 2000. Regional program for pollution control in the Tanning industry US/RAS/92/120 in South-East Asia Pp $1-14$.

DWAF, 1992. Analytical Methods Manual, TR 151. Department of Water Affairs and Forestry, Pretoria.

EPA., 2003f. Effluent guidelines and standards. General provisions. Toxic pollutants.

Washington, DC: U.S. Environmental Protection Agency, 2003. 40 CFR 401.15. http://www.epa.gov/epahome/cfr40.htm.June 06, 2003.

EPA, 2003p. Standards for the use or disposal of sewage sludge. Pollutant limits. Washington, DC: U.S. Environmental Protection Agency. 40CFR 503.13.

http://www.epa.gov/epahome/cfr40.htm. June 06, 2006.

Felsner, G., 2003. Technical Report: "Improving Tannery pollution control in Kano" Prepared for the Government of Nigeria by UNIDO. YA/NIR/03/440/11-52.

Flyoyd, W.B. and Hezekiah, S., 1997. Analysis of coal ash by atomic absorption spectrometric and spectrophotometric methods. In: Method for sampling and inorganic Analysis of Coal. USA. Geological Survey Bulletin 1823. Golightly D.W and Simon F.O. (Ed). 1-20.

Ghoreishi, S. M and Haghighi, R., 2003. Chemical catalytic reaction and biological oxidation for Treatment of non-biodegradable textile effluent, Chemical Engineering Journal. 95: 163-169.

Kupechella, C. E. and Hyland, M. C., 1989. Environmental Science, Allyn and Baron, London.
Novick R., 1999. Overview and the Health in Europe in the 1990s, World Health Organization, Europe Regional Office, Copenhagen, EUR/ICP/EH/CO 0202 05/6, pp 20.

Olanrewaju, D. O., 2001. Urban infrastructure renewal process in ljora Badia. Lagos. Habitat International. 25: 373-479.

PRG, Pollution Research Group, 1998. Waste Minimization Guide for Textile Industry -A Step towards cleaner production, University of Natal, Draft Volumes 1 and 2.

Radojevic, M. and Bashkin, V. N., 1999. Practical Environmental Analysis. The Royal Society of Chemistry, Cambridge pp 466.

SDPI,1995. Environmental examination of the textile industry in Pakistan project on technology transfer for sustainable industrial development, Islamabad: SDPI.

Standard Methods, 1976. Standard method for the examination of water and wastewater $\left(14^{\text {th }}\right.$ edn $)$ Jointly published by the American Public Health Association, America Water Works Association and Water Pollution Control Federation, Washington, DC. Pp 68-165.

Talbot, R. S., 1979. Industrial Waste-Textile Waste, Journal of Water Pollution Control Federation (7): pp 279-331.

UNIDO, 2005. United Nations Industrial Development Organization, Cost of Tanned Waste Treatment, 15th Session of the Leather and Leather Products Industry Panel, Leon, Mexico.

USEPA. 1999. Volunteer lake monitoring: A methods manual. EPA 440/4-91-002. Office of water. U.S Environmental Protection Agency, Washington, DC.file://AlHydrology and Water Quality of Lake Merced.htm.

Uzo, B.G., Edward, E.O., Fredrick, A.L. and Lawerence, D. O., 2006. Analysis of tannery effluents from the Challawa Industrial Estate in Kano, Nigeria Global. J. Pure. Appl. Sci. 12: 6972.

WHO, 1984. Guidelines for drinking water quality. Geneva, Switzerland: World Health Organization. http://www.who.int/en/. June 06, 2003.

WHO, 1993. Guidelines for Technologies for Water Supply Systems in Small Communities, World Health Organization, CEHA 1993.

WHO, 2002. Water Pollutants: Biological Agents, Dissolved Chemicals, Non-dissolved Chemicals, Sediments, Heat, WHO CEHA, Amman, Jordan.

WHO, 2003. The World Health Report 2003: Shaping the Future, World Health Organization, 1211Geneva 27, Switzerland. 